\title{
Variability in motility characteristics among marine bacteria
}

\author{
Jens Efsen Johansen ${ }^{1}$, Jarone Pinhassi ${ }^{2, *}$, Nicholas Blackburn ${ }^{3}$, Ulla Li Zweifel ${ }^{4}$, \\ Åke Hagström ${ }^{4}$
}

${ }^{1}$ Microbial Ecology and Biotechnology, National Environmental Research Institute, Frederiksborgvej 399, 4000 Roskilde, Denmark

${ }^{2}$ Departament de Biologia Marina i Oceanografia, Institut de Ciències del Mar-CMIMA (CSIC), Passeig Marìtim de la Barceloneta 37-49, 08003 Barcelona, Spain

${ }^{3}$ Marine Biological Laboratory, University of Copenhagen, Strandpromenaden 5, 3000 Helsingør, Denmark

${ }^{4}$ Marine Science, Kalmar University, PO Box 905, 39129 Kalmar, Sweden

\begin{abstract}
Motility characteristics of a phylogenetically diverse collection of widespread marine bacteria were investigated using phase contrast microscopy in combination with digital image analysis. Thirty-eight isolated bacteria were identified by sequencing the $16 \mathrm{~S}$ rDNA and an additional 46 unidentified isolates were included in this study. The identified bacteria were $\gamma$-Proteobacteria (e.g. Vibrio and Pseudoalteromonas), $\alpha$-Proteobacteria (e.g. Roseobacter and Caulobacter), members of the Cytophaga group and a Gram-positive strain. The mean swimming speed of the investigated bacteria growing in Zobell medium ranged from 11 to $38 \mu \mathrm{m} \mathrm{s}^{-1}$, with a majority of the bacteria having a mean speed of 15 to $25 \mu \mathrm{m} \mathrm{s}^{-1}$. Maximum speeds reached $75 \mu \mathrm{m} \mathrm{s}^{-1}$. Acceleration ranged from 80 to

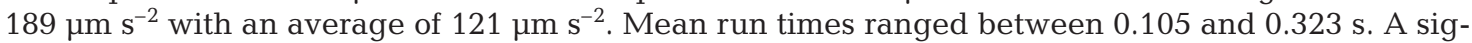
nificant positive correlation between growth rate and mean swimming speed was found. A total of $70 \%$ of the bacterial isolates showed a turn angle larger than $150^{\circ}$ (range 127 to $180^{\circ}$ ), demonstrating that reversal of swimming direction is an important strategy for bacteria in the marine environment, in contrast to the biased random walk exhibited by enteric bacteria.
\end{abstract}

KEY WORDS: Bacterial motility $\cdot$ Swimming speed $\cdot$ Acceleration $\cdot$ Nutrient patches $\cdot$ Bacterioplankton Resale or republication not permitted without written consent of the publisher

\section{INTRODUCTION}

Motility allows a bacterium to explore its nearby environment in the quest for food. In the organic matter continuum of seawater, within which bacteria maneuver, nutrients are found dissolved and bound in particles (Azam 1998). Upon lysis and decay of particles, microscale nutrient patches develop, resulting in a diffusion gradient that can elicit the chemotactic response of bacteria (Blackburn et al. 1997, 1998a, Blackburn \& Fenchel 1999). Modeling of molecular diffusion rates from lysed algal cells suggests a longevity of such nutrient patches of up to 10 min (Blackburn et al. 1998a). Similarly, studies of solute distribution around sinking aggregates

*Corresponding author. E-mail: jarone@cmima.csic.es suggest that nutrient plumes from sinking aggregates $0.5 \mathrm{~cm}$ in size would last $13 \mathrm{~min}$ (Kiørboe et al. 2001). Within these time scales, motile bacteria have the opportunity to exploit patches (Blackburn et al. 1998a, Kiørboe et al. 2001). Thus, an efficient utilization of microscale nutrient patches by swimming offers a mechanism for supporting high bacterial growth rates independent of low background concentrations.

The basic knowledge of bacterial motility is derived from studies of chemotactic behavior of enteric bacteria (for references see e.g. Adler 1966, Berg \& Brown 1972). The swimming behavior of Escherichia coli is characterized as a biased random walk where run lengths towards an attractant are longer than runs away from the attractant (Berg \& Brown 1972). Typically, run periods are interrupted by stops when cells 
rotate/tumble and reorient randomly, largely due to Brownian motion. After this reorientation, a new run is initiated. However, direct observation of bacterioplankton and laboratory experiments involving a few specified bacterial strains have demonstrated a considerable variability in swimming behavior of bacteria (Mitchell et al. 1995b). The swimming speed of E. coli is around $15 \mu \mathrm{m} \mathrm{s}^{-1}$ with a maximum acceleration of $70 \mu \mathrm{m} \mathrm{s}^{-2}$ (Berg \& Brown 1972, Mitchell et al. 1995b). Much higher speed and acceleration, up to $230 \mu \mathrm{m} \mathrm{s}^{-1}$ and $1450 \mu \mathrm{m} \mathrm{s}^{-2}$, respectively, has been demonstrated for some marine bacteria (Mitchell et al. 1995b). Very fast flagellar rotation has been shown to allow the bacterium Vibrio alginolyticus to move at speeds up to $150 \mathrm{\mu m} \mathrm{s}^{-1}$ (Magariyama et al. 1994). For the large sulfur/sulfide-oxidizing bacterium Thiovulum majus (5 to $25 \mu \mathrm{m}$ in diameter), speeds exceeding $600 \mu \mathrm{m} \mathrm{s}^{-1}$ have been recorded (Fenchel 1994). The high speed of this species is proposed to be important for the bacterium to respond to changing sulfur/sulfide concentrations at sediment surfaces.

Theoretical modeling of bacterial motility has indicated cell size to be an important determinant of motility characteristics (Mitchell 1991, Dusenbery 1997). Mitchell (1991) simulated motility tracks of bacteria in 4 different size classes ranging from 0.2 to $1.0 \mu \mathrm{m}$ in diameter and a speed in these size classes of $20 \mu \mathrm{m} \mathrm{s}^{-1}$, demonstrating that bacteria $1.0 \mu \mathrm{m}$ in diameter would have a smooth and straight track whereas very small bacteria would have a short twisted track. An explanation for these differences was inferred from the high cost of compensation for fast rotation induced by Brownian motion for small cells compared to big cells (Mitchell 1991). In a model analysis, Dusenbery (1997) hypothesized that there is a size limit of about $0.6 \mu \mathrm{m}$ below which motility has no benefit. In reviewing existing descriptions of bacterial genera, he found that members of typically motile genera had cell lengths of more than $0.8 \mu \mathrm{m}$, whereas smaller bacteria could be found among non-motile genera. Thus, it appears likely that bacteria belonging to different phylogenetic groups, having different cell shapes and sizes, also have different motility characteristics.

Phylogenetic analyses have revealed a substantial diversity among marine bacterioplankton (Ward et al. 1990, Fuhrman et al. 1992, Suzuki et al. 1997, Hagström et al. 2000). Ascribing functional behavior to these bacteria is an important step in understanding their role in the turnover of e.g. nutrients and dissolved organic carbon (Martinez et al. 1996, Pinhassi et al. 1999, Cottrell \& Kirchman 2000). In the present work, a first attempt to describe motility characteristics of a phylogenetically diverse collection of marine bacteria was made. Phase contrast microscopy in combination with image analysis revealed a significant variability in mean and maximum swimming speed and acceleration among different bacteria, as well as a turn angle motif that corroborates the finding that marine bacteria may remain in nutrient patches.

\section{MATERIALS AND METHODS}

Bacterial strains. A total of 84 motile bacteria were selected from a section of a culture collection of bacteria (186 bacteria screened) isolated from different geographical areas worldwide (Hagström et al. 2000). Of the 84 bacteria, 38 isolates were partially sequenced (approximately $500 \mathrm{bp}$ ), using ABI PRISM dye terminator cycle sequencing (Perkin Elmer), as previously described (Pinhassi et al. 1997). The closest relative of the sequenced isolates in GenBank is indicated in Table 1.

Determination of growth rates. For determination of growth rates, bacteria were grown in Zobell medium (ZoBell 1946). An overnight culture was transferred to a 96-well microplate (Costar) with $150 \mu \mathrm{\mu l}$ Zobell medium in each well. For each bacterial strain, a decimal dilution was performed and incubated at $15^{\circ} \mathrm{C}$ on a shaking table (200 rpm). To reduce evaporation and the risk of cross-contamination, a piece of ParaFilm (American National Can) was placed between the lid and the microplate. Bacterial growth was measured by the increase in optical density in a spectrophotometer (BIO-TEK instruments Microplate Autoreader EL311) at $590 \mathrm{~nm}$ approximately every $1 \mathrm{~h}$. Replicates of growth rate measurements were not performed. When bacteria were in exponential phase, a subsample was taken for bacterial size determination by filtering onto $0.2 \mu \mathrm{m}$ pore-size black polycarbonate filters and stained for 5 min with a $0.003 \%$ acridine orange solution (Hobbie et al. 1977). Size of bacteria was determined from digital images of cells visualized by epifluorescence microscopy and analyzed by the software LabMicrobe, as previously described (Blackburn et al. 1998b). Width of cells was chosen as a more robust measure of cell size than length, due to difficulties in differentiating actively dividing from newly divided cells.

Bacterial motility characteristics. Bacterial motility characteristics were monitored through a microscope (Zeiss orthoplan) equipped with a $25 \times$ objective. The microscope was connected to a CCD camera (Panasonic, video camera F15) which in turn was connected to a super-VHS video recorder (Panasonic NV FS90) and a color TV screen. A flat capillary glass tube (70 mm long, $4 \mathrm{~mm}$ wide, $1 \mathrm{~mm}$ high) was connected at both ends with silicone tubes to facilitate the suction of cell cultures into the capillary. The flat capillary tube was fixed to a glass slide with glue. A suspension with 


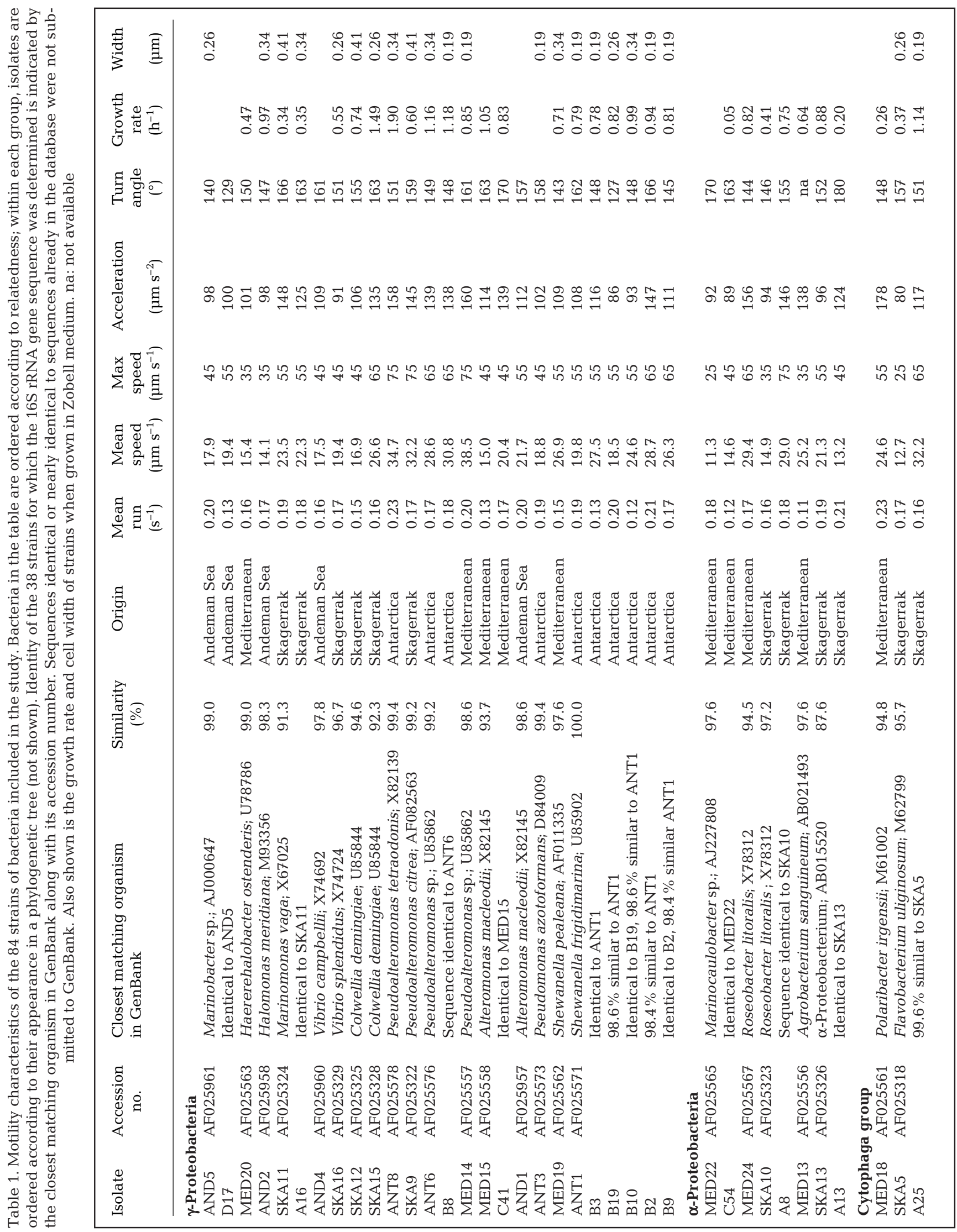




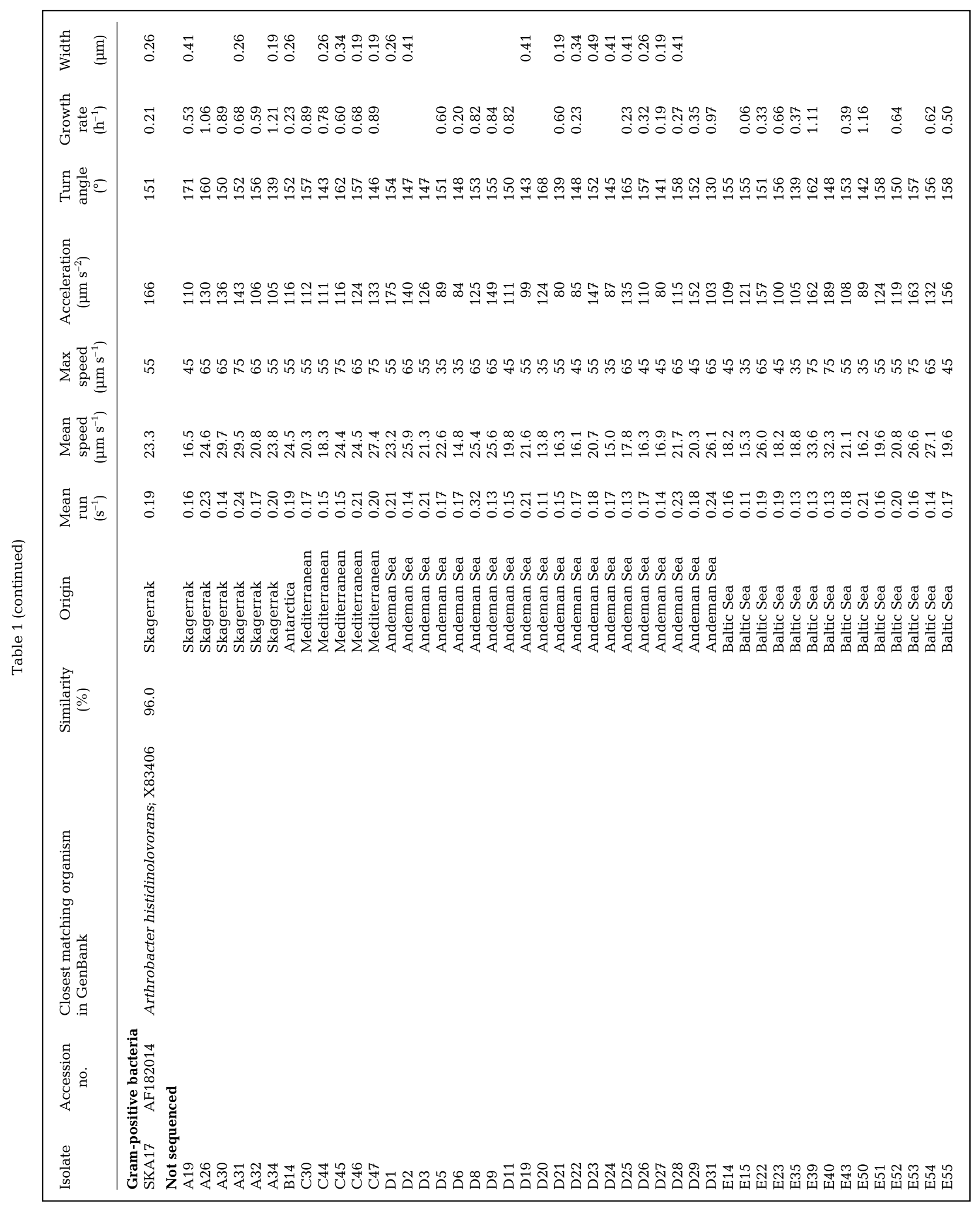


exponentially growing bacteria was sucked into the capillary tube and monitored. When water flow stopped in the tube, a 10 to $60 \mathrm{~s}$ video sequence of the bacteria was recorded. Although the temperature in the capillary tube was not measured, the short time of direct observation and exposure to the light source should have had little impact on the behavior of isolates. Similarly, the short time of observation should not have allowed the development of a significant chemical gradient inducing chemotaxis in the capillary tube. Between each sample, the flat capillary tube was rinsed with sterile MilliQ-water, and the capillary tube was regularly rinsed with $5 \mathrm{M} \mathrm{NaOH}$ and then rinsed several times with sterile MilliQ-water to reduce formation of residue inside the capillary tube.

Handling of video sequence. Recordings were digitized at 25 frames s ${ }^{-1}$ to computer memory. Approximately 200 frames were used for further analysis. A computer program (LabTrack) was used for tracking bacteria (Blackburn et al. 1998a, Blackburn \& Fenchel 1999). There were usually about 100 bacteria present in the field of view. Calculations of motility parameters were based on running means over 3 frames. Tracks showing a maximum speed below a threshold value of $13 \mu \mathrm{m} \mathrm{s}^{-1}$ were filtered out to avoid interference of unspecific particles with the motility measurements. The threshold should also have filtered out cells moving awkwardly and very slowly due to being in the phase of active division with e.g. incomplete or counteracting flagellation. However, in our experience, the fraction of actively dividing cells, e.g. in the phase of septum formation, in exponentially growing cultures is typically $<10 \%$. Although the lower threshold could result in an increased average speed for the studied isolates, inspection of the normally distributed speed measurements for each of the isolates revealed very few tracks in the vicinity of the threshold value. The upper speed limit of the tracking system was $130 \mu \mathrm{m} \mathrm{s}^{-1}$. Tumbles were detected by changes in trajectory angle exceeding $50^{\circ}$. This could result in an overestimation of the turn angle of the isolates. However, inspection of the frequency distribution around the mean turn angle for each of the isolates revealed few tracks in this low range. The limited depth of field (around $10 \mu \mathrm{m})$ effectively filtered out tracks that were not moving at a shallow angle relative to the plane of view. Yet, it is likely that, for example, run distance and turn angle were slightly underestimated since tracks not moving perfectly in the plane of view are interpreted as projections onto that plane.

\section{RESULTS}

Four examples of different swimming behavior by different bacterial species are shown in Fig. 1. Vibrio cambellii showed tracks with long stops between swimming periods (Fig. 1A). Halomonas meridiana demonstrated helix shaped tracks (Fig. 1B). Flavobacterium sp. illustrated bacteria with fast and straight swimming tracks (Fig. 1C). Shewanella frigidimarina showed sharp turns at an average speed (Fig. 1D). The variability in behavior among replicate cultures of the same isolate was not determined. To verify the experimental setup, we investigated the variability in motility characteristics between 7 pairs of bacteria with $16 \mathrm{~S}$ rDNA sequences identical in the 500 bp region. Motility parameters were very similar between isolates within 5 of the pairs. The remaining 2 pairs displayed differences (i.e. SKA10-A8, SKA13-A13), although in these cases, the isolates showed a 2 -fold difference in growth rate. We also investigated 6 isolates with a sequence similarity of 98.4 to $100 \%$ to $S$. frigidimarina (Fig. 2). In most cases, these isolates revealed a high

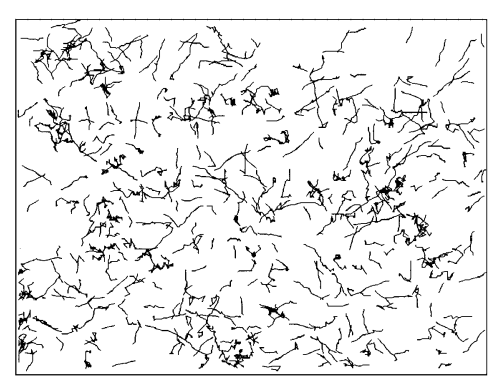

(A)

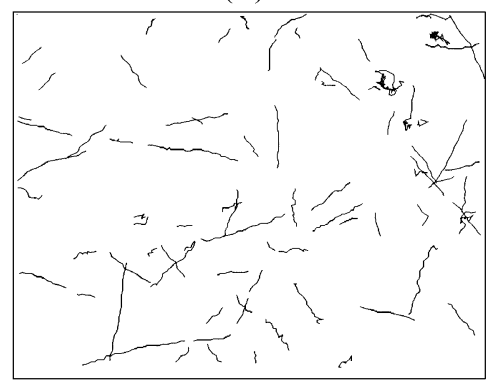

(C)

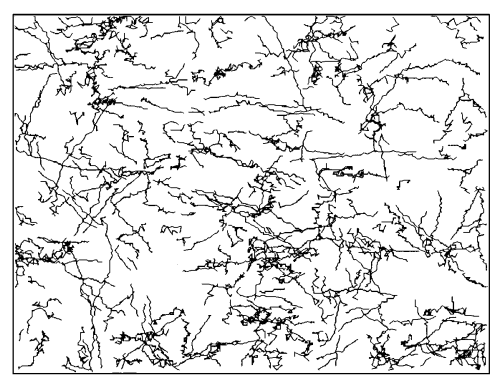

(B)

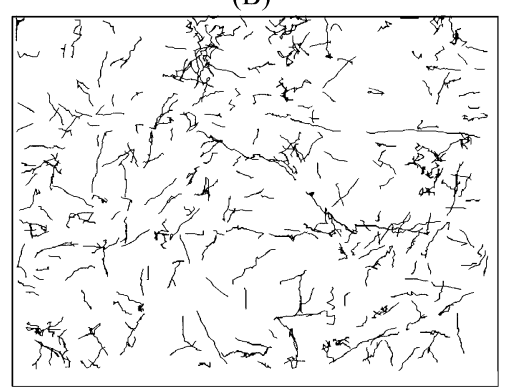

(D)

Fig. 1. Digitized tracks showing examples of different swimming behavior by 4 marine bacteria. (A) Vibrio cambellii with tracks with long stops between swimming periods; (B) Halomonas meridiana with helix shaped tracks; (C) Flavobacterium sp. with fast and straight swimming tracks; (D) Shewanella frigidimarina with average speed and sharp turns. See Table 1 for data on motility characteristics of the 4 bacteria 
similarity of motility characteristics. Taken together, the small differences observed in these comparisons should indicate a good reproducibility of our motility assay.

The motility characteristics of the studied bacteria are presented in Table 1. The mean swimming speed measurements for each of the 84 investigated bacteria ranged from 11.3 to $38.5 \mu \mathrm{m} \mathrm{s}^{-1}$, with a majority of the bacteria having a mean speed of 15 to $25 \mu \mathrm{m} \mathrm{s}^{-1}$. The mean run time, i.e. duration of runs between tumbles, ranged from 0.105 to $0.323 \mathrm{~s}$ with a majority between 0.150 and $0.200 \mathrm{~s}$. Observed speed and run time gave run lengths between 2 and $8 \mu \mathrm{m}$ for the studied bacteria. These distances are similar to those reported by Blackburn et al. (1998a) for bacteria clustering around algal cells. In their experiment, bacteria swimming away from algae showed run lengths between 2 and $5 \mu \mathrm{m}$ while bacteria swimming towards algae showed run lengths of 6 to $11 \mu \mathrm{m}$ (Blackburn, et al. 1998a). Much longer run lengths (around $115 \mu \mathrm{m}$ ) have been recorded for fast bacteria observed in seawater enriched with nutrients (Mitchell et al. 1996).

The acceleration of the studied bacteria ranged from 80 to $189 \mu \mathrm{m} \mathrm{s}^{-2}$ with an average of $121 \mu \mathrm{m} \mathrm{s}^{-2}$. There was a significant positive correlation between mean speed and acceleration (linear regression: $y=2.9 x+$ $56.9 ; \mathrm{R}^{2}=0.43, \mathrm{p}<0.005, \mathrm{n}=84$ ). For most of the isolates, we determined specific growth rate in culture and observed large variations between isolates (Table 1). There was a significant positive correlation between growth rate and mean speed (linear regression: $\left.y=8.6 x+16.7 ; \mathrm{R}^{2}=0.27, \mathrm{p}<0.001, \mathrm{n}=67\right)$. There was no correlation between size of the bacteria and the measured motility characteristics. A total of $70 \%$ of the bacterial isolates showed a turn angle larger than $150^{\circ}$ (range 127 to $180^{\circ}$ ), essentially indicating a reversal of swimming direction after a stop.

The identified motile bacteria belonged to 4 major taxonomic groups (Table 1) and based on the 16S rRNA gene sequences, belonged to at least 25 different species. Seventeen different species within the $\gamma$-Proteobacteria were studied, with representatives found among a wide variety of genera in the group, e.g. Vibrio, Pseudoalteromonas, Shewanella and Pseudomonas. Bacteria in the genera Vibrio, Marinobacter and Halomonas all showed mean velocities between 14 and $19 \mu \mathrm{m} \mathrm{s}^{-1}$, while the 4 investigated species of Pseudoalteromonas showed high mean velocities, between 28 and $38 \mu \mathrm{m} \mathrm{s}^{-1}$, and high maximum speeds. $\alpha$-Proteobacteria were represented by 5 different taxa, including 2 members of the genus Roseobacter. The lowest mean speed in the study was recorded for the $\alpha$ Proteobacterium Marinocaulobacter sp. MED22. The Cytophaga group was represented by 2 species, of which Polaribacter sp. MED18 showed the highest acceleration in the study. The Gram-positive bacterium included in the study showed average speed and high acceleration.

\section{DISCUSSION}

With the aim of studying motility of isolated bacteria, we had to make a decision on which growth medium to use for the cultures. This decision is not trivial since it is generally known that bacterial physiology and motil-

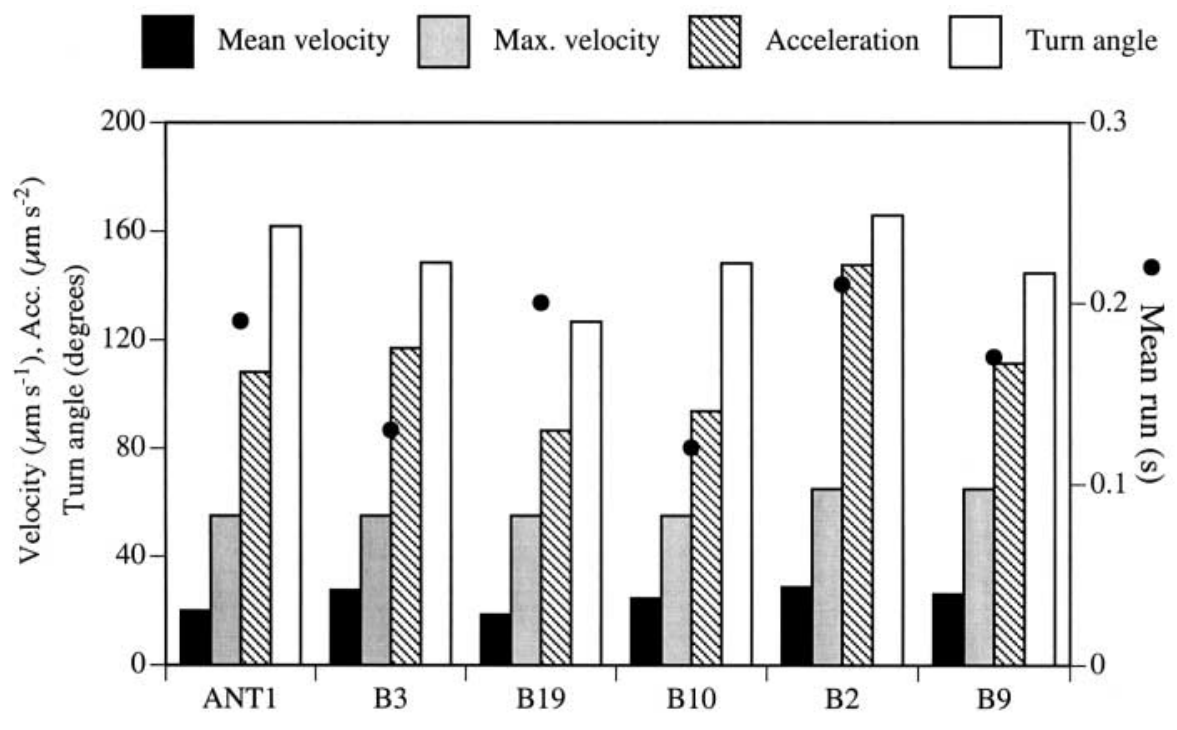

Fig. 2. Comparison of motility characteristics of 6 strains with a $16 \mathrm{~S}$ rDNA sequence similarity between 98.4 and $100 \%$ to Shewanella frigidimarina. Isolates on the $x$-axis are ordered by $16 \mathrm{~S}$ rDNA similarity to ANT1 
ity is largely dependent on the growth conditions encountered (Maaløe \& Kjeldgaard 1966, Kjelleberg et al. 1993, Eberl et al. 1999). Concerning motility it has been demonstrated that lower swimming speeds are recorded in rich media compared to tests in 100-fold diluted media, suggesting that low nutrient availability might stimulate motility (Mitchell et al. 1995a). However, in the same experiment, Mitchell and coworkers (1995a) found swimming speeds in filtered seawater that were similar to the speeds recorded in undiluted media. Therefore, we decided to use the Zobell medium for convenience as well as to ensure that the medium and the growth conditions were kept uniform in all tests. Although not tested, we have assumed that the reported differences and similarities in swimming behavior between our isolates are general features and not medium specific. The absolute values provided as motility data from laboratory experiments may not be directly transferred and discussed in the context of natural environments without consideration of the methodological limitations. However, in relative terms, our investigation should provide a valuable comparison between different bacteria.

The present study revealed a large variability in swimming behavior among different species of marine bacteria. Differences were seen not only in speed but also in the pattern of motility of different bacteria, e.g. the fast Flavobacterium strain A25 showed long straight run tracks whereas the slow Halomonas meridiana showed short helix shaped tracks (Fig. 1). Mean velocities among our studied bacteria varied 4fold, between 11 and $38 \mu \mathrm{m} \mathrm{s}^{-1}$ and maximum velocities up to $75 \mu \mathrm{m} \mathrm{s}^{-1}$ were measured. Comparable values have been recorded in studies of motility characteristics of bacterioplankton in coastal waters of Australia, where community speeds of 30 to $45 \mu \mathrm{m} \mathrm{s}^{-1}$ were demonstrated (Mitchell et al. 1995a,b). An interesting case for comparison is offered by our representatives of the exclusively marine genus Pseudoalteromonas, which displayed values of 65 to $75 \mu \mathrm{m} \mathrm{s}^{-1}$ and $140 \mu \mathrm{m} \mathrm{s}^{-2}$ for speed and acceleration, respectively. This is similar to the motility characteristics of the fast swimming bacterium $P$. haloplanktis isolated by Mitchell et al. (1995b), which could reach a speed of $62 \mu \mathrm{m} \mathrm{s}^{-1}$ and an acceleration of $166 \mu \mathrm{m} \mathrm{s}^{-2}$. Furthermore, the average acceleration of $121 \mu \mathrm{m} \mathrm{s}^{-2}$ for all our isolates is essentially identical to the acceleration of $120 \mu \mathrm{m} \mathrm{s}^{-2}$ measured for a natural bacterioplankton community (Mitchell et al. 1995b). Although the motility characteristics of our bacteria are similar to those measured in marine bacterioplankton and to the few previously characterized marine isolates, it should be pointed out that much higher speed and acceleration, up to $305 \mu \mathrm{m} \mathrm{s}^{-1}$ and $1450 \mu \mathrm{m} \mathrm{s}^{-2}$, respectively, have been recorded for marine bacteria in tight micro- swarms and in microbial mats (Mitchell et al. 1995a,b, Barbara \& Mitchell 1996). These high values could be the result of induction of speed by environmental conditions stimulating swarming of otherwise moderately fast bacteria. It could also result from selective growth of fast species of bacteria in response to nutrients added and subsequent incubation (Mitchell et al. 1995a, Fenchel 2001, Grossart et al. 2001).

Among aquatic bacteria, a markedly different swimming behavior from that of enteric bacteria has been recorded. Instead of tumbling and reorienting randomly upon stopping, several marine isolates show a reversal of the swimming direction after a stop (Mitchell 1991, Mitchell et al. 1996, Blackburn et al. 1998a). Most of our isolates displayed turn angles larger than $150^{\circ}$, indicating that reversal is an ability harbored by many different taxa of marine bacteria. This ability allows the bacteria to effectively return to a favorable patch. Computer assisted modeling performed by Blackburn et al. (1998a) has demonstrated this swimming strategy to be important for the efficiency of the chemotactic response of marine bacteria. Reversal of direction was required in the model to reproduce observed patterns of clustering of bacteria around a potential nutrient source in natural samples. Clustering was not observed when the turn angle after a stop was decreased to $90^{\circ}$ (Blackburn et al. 1998a).

It has recently been demonstrated that nutrient patches 2 to $3 \mathrm{~mm}$ in diameter caused by cell lysis and predation events, can sustain clustering of swimming bacteria up to $10 \mathrm{~min}$; the size of patches and their persistence depending on the size of the lysing particle (Blackburn et al. 1998a). Bacteria that encounter these patches, and subsequently utilize them, could obtain higher growth rates than bacteria remaining outside patches. Thus, if nutrient patches are generated randomly in time and space, it is advantageous to swim (Blackburn \& Fenchel 1999). Based on microscale experiments and theoretical modeling, it has been suggested that fast swimming would be advantageous in rich environments with large nutrient patches; whereas, in more nutrient depleted pelagic environments, low swimming speeds would be more consistent (Blackburn \& Fenchel 1999). These authors also calculated that in the pelagic environment, where nutrient patches are likely to be small, a speed of just $10 \mu \mathrm{m} \mathrm{s}^{-1}$ is enough for a bacterium to obtain a significant gain in patch encounter. A majority of our motile bacteria showed mean velocities in the range of 20 to $40 \mu \mathrm{m} \mathrm{s}^{-1}$, and maximum velocities up to $75 \mu \mathrm{m} \mathrm{s}{ }^{-1}$. Since swimming speed is the most influential motility parameter contributing to increased nutrient exposure by chemotaxis (Blackburn \& Fenchel 1999), it appears that the motility of these marine bacteria could result in a significant gain in growth rate. 
Our results demonstrated that bacteria with high specific growth rates showed higher swimming speeds than slow growing bacteria, suggesting that a high metabolic activity could be a prerequisite for rapid swimming. Yet, we found no correlation between cell size and speed. Although modeling work has suggested that size is important in determining motility characteristics of bacteria (Mitchell 1991), models cannot accurately predict the stabilizing effects of flagella and cell shape, and the range in cell width of 0.2 to $0.5 \mu \mathrm{m}$ for bacteria in this study may not have been enough to show a correlation if it exists. Generally, it is known that the size of a bacterial cell in a particular medium is primarily governed by growth rate (Maaløe \& Kjeldgaard 1966). In Escherichia coli, fast growth is possible due to the ability of cells to massively increase its number of ribosomes in response to favorable growth conditions. To accommodate the large number of ribosomes, the cell size increases (Maaløe \& Kjeldgaard 1966, Wagner 1994). However, despite its high metabolic capability, $E$. coli is not a fast swimmer and high growth rates in conjunction with fast swimming might well reflect an adaptation to a patchy environment, as is the case for the large Thiovulum majus (Fenchel 1994). The basis for differences in swimming speed between various bacteria is likely to be found in their physiology. It has been suggested that differences in rotational rates, and thereby speed, between different flagellar motors $\left(\mathrm{H}^{+}\right.$and $\mathrm{Na}^{+}$-driven), may be explained by variability in efficiency of the energy coupling of the motors (Yorimitsu \& Homma 2001). Thus, the $\mathrm{Na}^{+}$-driven flagellar motor, like the one found in Vibrio species, is inferred to be the fastest yet known (Yorimitsu \& Homma 2001).

This study is perhaps the first systematic survey of the motility behavior in a relatively large gene pool, and as such, it gives an important insight into the general diversity in motility behavior. It appears that a significant proportion of bacteria in natural aquatic ecosystems is motile (Fenchel 2001, Grossart et al. 2001) and if the concept of a patchy and stringy world as experienced by aquatic microorganisms holds true (Blackburn et al. 1997, 1998a, Azam 1998, Kiørboe, et al. 2001), an awareness of the ability of bacteria to seek and home in on microscale nutrient patches could have significant consequences for the understanding of nutrient turnover and energy flow in the sea.

Acknowledgements. We are thankful for the valuable comments and criticism on the manuscript provided by Celia Marrasé and 3 anonymous reviewers. This work was supported by the Danish National Environmental Research Institute, Roskilde, Denmark; by grant B650-19981070 from the Swedish Natural Science Research Council (NFR); and by grants from The Royal Swedish Academy of Sciences (KVA) and The Swedish Foundation for International Cooperation in Research and Higher Education (STINT) to J.P.

\section{LITERATURE CITED}

Adler J (1966) Chemotaxis in bacteria. Science 153:708-716

Azam F (1998) Microbial control of oceanic carbon flux: the plot thickens. Science 280:694-696

Barbara GM, Mitchell JG (1996) Formation of 30- to 40micrometer-thick laminations by high-speed marine bacteria in microbial mats. Appl Environ Microbiol 62:3985-3990

Berg HC, Brown DA (1972) Chemotaxis in Escherichia coli analyzed by three-dimensional tracking. Nature 239:500

Blackburn N, Fenchel T (1999) Influence of bacteria, diffusion and shear on micro-scale patches, and implications for bacterial chemotaxis. Mar Ecol Prog Ser 189:1-7

Blackburn N, Azam F, Hagström $\AA$ (1997) Spatially explicit simulations of a microbial food web. Limnol Oceanogr 42:613-622

Blackburn N, Fenchel, T Mitchell J (1998a) Microscale nutrient patches in planktonic habitats shown by chemotactic bacteria. Science 282:2254-2256

Blackburn N, Hagström Å, Wikner J, Cuadros-Hansson R, Koefoed Bjørnsen P (1998b) Rapid determination of bacterial abundance, biovolume, morphology, and growth by neural network-based image analysis. Appl Environ Microbiol 64:3246-3255

Cottrell MT, Kirchman DL (2000) Natural assemblages of marine Proteobacteria and members of the CytophagaFlavobacter cluster consuming low- and high-molecularweight dissolved organic matter. Appl Environ Microbiol 66:1692-1697

Dusenbery DB (1997) Minimum size limit for useful locomotion by free-swimming microbes. Proc Natl Acad Sci USA 94:10949-10954

Eberl L, Molin S, Givskov M (1999) Surface motility of Serratia liquefaciens MG1. J Bacteriol 181:1703-1712

Fenchel T (1994) Motility and chemosensory of the sulphur bacterium Thiovulum majus. Microbiology 140:3109-3116

Fenchel T (2001) Eppur si muove: many water column bacteria are motile. Aquat Microb Ecol 24:197-201

Fuhrman JA, McCallum K, Davis AA (1992) Novel major archaebacterial group from marine plankton. Nature 356:148-149

Grossart HP, Riemann L, Azam F (2001) Bacterial motility in the sea and its ecological implications. Aquat Microb Ecol 25:247-258

Hagström ̊, Pinhassi J, Zweifel UL (2000) Biogeographical diversity among marine bacterioplankton. Aquat Microb Ecol 21:231-244

Hobbie JE, Daley RJ, Jasper S (1977) Use of nucleopore filters for counting bacteria by fluorescence microscopy. Appl Environ Microbiol 33:1225-1228

Kiørboe T, Ploug H, Thygesen UH (2001) Fluid motion and solute distribution around sinking aggregates. I. Smallscale fluxes and heterogeneity of nutrients in the pelagic environment. Mar Ecol Prog Ser 211:1-13

Kjelleberg S, Östling J, Holmquist L, Flärdh K, Svenblad B, Jouper-Jaan $\AA$, Weichart D, Albertsson N (1993) Starvation and recovery of Vibrio. In: Guerrero R, Pedrós-Alió C (eds) Trends in microbial ecology. Spanish Society for Microbiology, Barcelona, p 169-174

Maaløe O, Kjeldgaard NO (1966) Control of macromolecular synthesis. WA Benjamin, New York

Magariyama Y, Sugiyama S, Muramoto K, Maekawa Y, Kawagishi I, Imae Y, Kudo S (1994) Very fast flagellar rotation. Nature 371:752

Martinez J, Smith DC, Steward GF, Azam F (1996) Variability in ectohydrolytic enzyme activities of pelagic marine bac- 
teria and its significance for substrate processing in the sea. Aquat Microb Ecol 10:223-230

Mitchell JG (1991) The influence of cell size on marine bacterial motility and energetics. Microbiol Ecol 22:227-238

Mitchell JG, Pearson L, Bonazinga A, Dillon S, Khouri $H_{\text {, }}$ Paxinos R (1995a) Long lag time and high velocities in the motility of natural assemblages of marine bacteria. Appl Environ Microbiol 61:877-882

Mitchell JG, Pearson L, Dillon S, Kantalis K (1995b) Natural assemblages of marine bacteria exhibiting high-speed motility and large accelerations. Appl Environ Microbiol 61:4436-4440

Mitchell JG, Pearson L, Dillon S (1996) Clustering of marine bacteria in seawater enrichments. Appl Environ Microbiol 62:3716-3721

Pinhassi J, Zweifel UL, Hagström Å (1997) Dominant marine bacterioplankton species found among colony-forming bacteria. Appl Environ Microbiol 63:3359-3366

Editorial responsibility: James Hollibaugh, Athens, Georgia, USA
Pinhassi J, Azam F, Hemphälä J, Long RA, Martinez J, Zweifel UL, Hagström Å (1999) Coupling between bacterioplankton species composition, population dynamics, and organic matter degradation. Aquat Microb Ecol 17:13-26

Suzuki MT, Rappé MS, Haimberger ZW, Winfield H, Adair N, Ströbel J, Giovannoni SJ (1997) Bacterial diversity among small-subunit rRNA gene clones and cellular isolates from the same seawater sample. Appl Environ Microbiol 63:983-989

Wagner R (1994) The regulation of ribosomal RNA synthesis and bacterial cell growth. Arch Microbiol 161:100-106

Ward DM, Weller R, Bateson MM (1990) 16S rRNA sequences reveal numerous uncultured microorganisms in a natural community. Nature 345:63-65

Yorimitsu T, Homma M (2001) $\mathrm{Na}^{+}$-driven flagellar motor of Vibrio. Biochim Biophys Acta 1505:82-93

ZoBell CE (1946) Marine microbiology: a monograph on hydrobacteriology. Cronica Botanica, Waltham, MA

Submitted: January 14, 2002; Accepted: May 21, 2002

Proofs received from author(s): July 18, 2002 